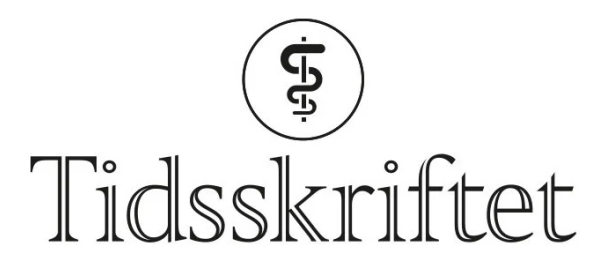

DEN NORSKE LEGEFORENING

\title{
Bakterielle odontogene infeksjoner
}

\author{
KLINISK OVERSIKT
}

\section{MATS DØVING}

matdov@ous-hf.no

Kjeve- og ansiktskirurgisk avdeling

Oslo universitetssykehus, Ullevål

Han har bidratt med idé, utforming, utarbeiding og revisjon av manuskriptet.

Mats Døving er lege i spesialisering i maksillofacial kirurgi. Han er også tannlegestudent ved det Odontologiske fakultetet, Universitetet i Oslo.

Forfatteren har fylt ut ICMJE-skjemaet og oppgir ingen interessekonflikter.

\section{TRUDE HANDAL}

Avdeling for endodonti

Det odontologiske fakultet

Universitetet i Oslo

Hun har bidratt med idé, utforming, utarbeiding og revisjon av manuskriptet.

Trude Handal er tannlege, dr.odont., spesialist i endodonti og førsteamanuensis.

Forfatteren har fylt ut ICMJE-skjemaet og oppgir ingen interessekonflikter.

\section{PÅL GALTELAND}

Kjeve- og ansiktskirurgisk avdeling

Oslo universitetssykehus, Ullevål

Han har bidratt med idé, utforming, utarbeiding og revisjon av manuskriptet.

Pål Galteland er lege og tannlege, spesialist i maksillofacial kirurgi og avdelingsleder/overlege.

Forfatteren har fylt ut ICMJE-skjemaet og oppgir ingen interessekonflikter.

\section{Odontogene infeksjoner er infeksjoner som oppstår i tennene og/eller i deres støttevev. Infeksjonene forekommer hyppig, og en stor andel av infeksjoner i hode- og halsregionen har odontogen opprinnelse. De fleste odontogene infeksjoner gir milde symptomer og funn, men kan utvikle seg til alvorlige tilstander.}

Denne artikkelen gir en oversikt over de vanligste patogene mikrobene i munnhulen, de hyppigst forekommende odontogene infeksjoner samt behandling og mulige komplikasjoner. Artikkelen er basert på et ikke-systematisk søk i PubMed, kliniske erfaringer og eget litteraturarkiv.

\section{Forårsakende mikrober}


Munnhulen inneholder over 700 naturlig forekommende bakteriearter. Streptokokker er en av de mest utbredte bakterieartene i munnhulen. Vanlige arter er S. mitis, S. sanguinis, S. salivarius og S. anginosus, og disse kan være medvirkende til utvikling av blant annet karies, marginal periodontitt og endokarditt (1).

Bakteriene i munnhulen er opportunister som kan forårsake infeksjon dersom samspillet mellom vert og mikrobe endres. I startfasen av en infeksjon gjenspeiler de ansvarlige mikrobene normalfloraen i munnhulen, men etter hvert som infeksjonen progredierer, vil anaerobe arter som regel dominere.

I tillegg til å forårsake lokale infeksjoner i bløt- og benvev, kan orale bakterier medvirke i utviklingen av Alzheimers sykdom, endokarditt, aterosklerose, osteomyelitt i ikkekraniofaciale knokler, revmatoid artritt og diabetes mellitus. Studier har også vist at

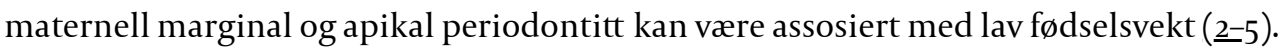

\section{Ordinære bakterielle odontogene infeksjoner}

\section{MARGINAL PERIODONTITT}

Tannkjøttsykdommen marginal periodontitt er en inflammatorisk tilstand som rammer tennenes støttevev. Studier har vist at ca. 50 \% av den voksne amerikanske befolkningen har marginal periodontitt og at $8 \%$ av 35 -åringer i Oslo har avansert periodontal destruksjon ( $\underline{6}$. 7.).

Sammenhengen mellom tilstanden og diabetes er veldokumentert, og pasienter med diabetes har $\emptyset \mathrm{kt}$ risiko for å utvikle marginal periodontitt - og motsatt (ㅁ) . Studier har vist at det også er en assosiasjon mellom marginal periodontitt og hjerte- og karsykdom, men det er foreløpig ikke nok evidens for å si at det foreligger et kausalt forhold (모).

Marginal periodontitt skyldes akkumulering av biofilm (plakk) langs tannkjøttranden. Dette gir en overfladisk infeksjon i gingiva (gingivitt) som kan føre til en dypere infeksjon langs tannroten (marginal periodontitt). Tilstanden er progredierende og kan til slutt føre til at tannen løsner. Røyking, diabetes og stress er kjente risikofaktorer ( $\underline{8})$.

Behandling av marginal periodontitt gjøres av tannlege eller tannpleier og består av mekanisk fjerning av plakk og tannstein. I enkelte tilfeller av aggressiv periodontitt er det indisert med antibiotika.

\section{APIKAL PERIODONTITT}

Rotkanalen er i utgangspunktet et sterilt, lukket system. Bakterier kan imidlertid nå kanalen via karies, frakturer, sprekker mellom fylling og tannsubstans og tannkjøttlommer. Påfølgende immunrespons med rekruttering og aktivering av leukocytter vil føre til inflammasjon av tannpulpa (pulpitt). Dette kan være svært smertefullt. Ubehandlet kan bakterier invadere tannpulpa og forårsake nekrose. Infeksjon i tannpulpa vil føre til inflammasjon i periodontalligamentet, og bakterieprodukter fra kanalen vil kunne migrere ut gjennom rotens apeks. Den påfølgende immunresponsen vil føre til inflammasjon og bendestruksjon periapikalt, såkalt apikal periodontitt (9.).

Tilstanden er oftest asymptomatisk. Dersom det tilkommer produksjon av puss, vil det dannes en periapikal abscess (figur 1 ). Tilstanden gir som regel hevelse, smerte og $\mathrm{i}$ varierende grad feber. Periapikale infeksjoner kan også spres til omkringliggende strukturer (figur 2). Hvis pusset dreneres via en fistel (ekstra- eller intraoralt), vil symptomene avta. Akutte periapikale abscesser må raskt dreneres for puss, enten via rotkanal eller ved incisjon. Det er primært tannleger som foretar behandlingen. 


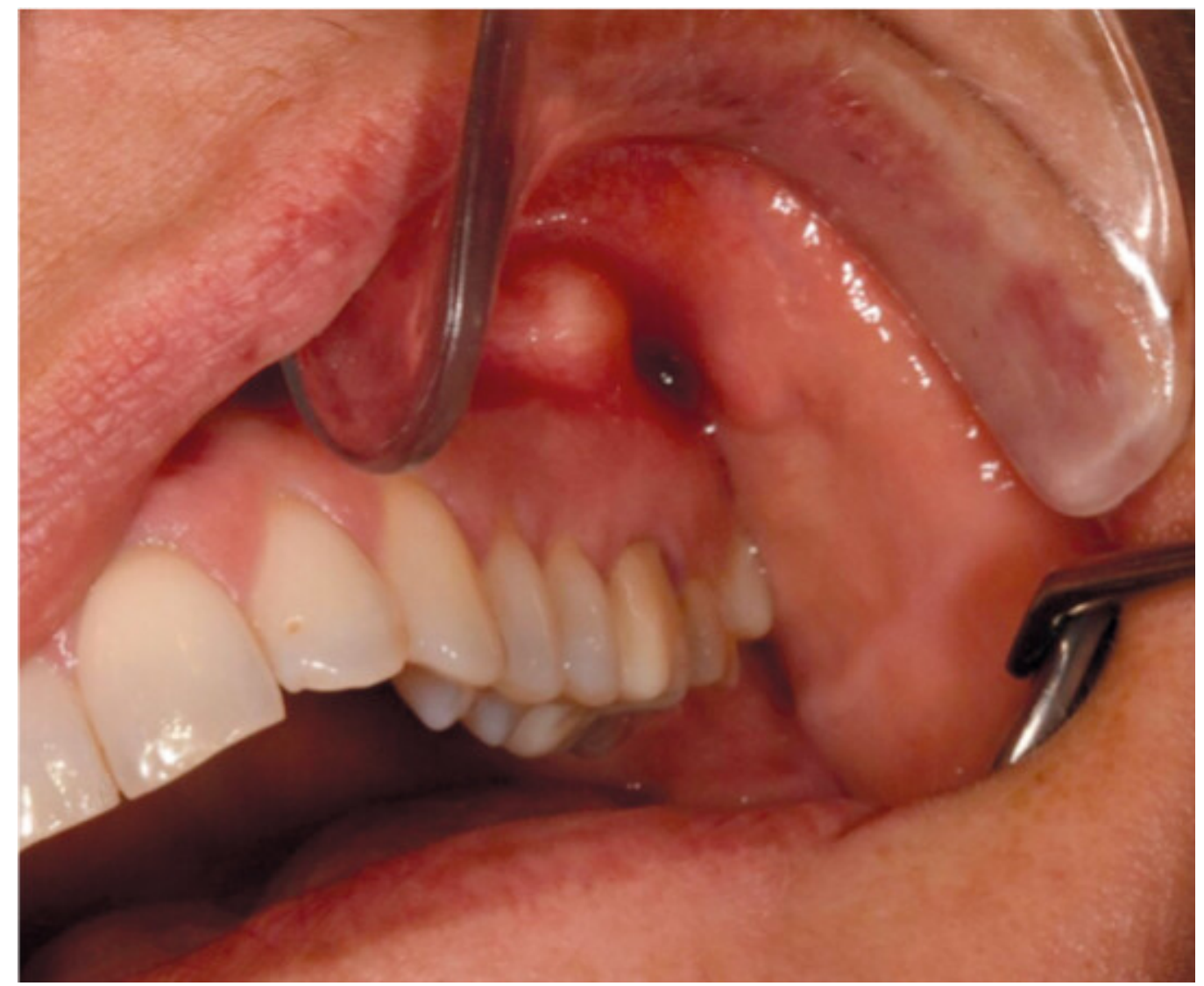

Figur 1 Periapikal abscess fra molar i overkjeven på venstre side. 


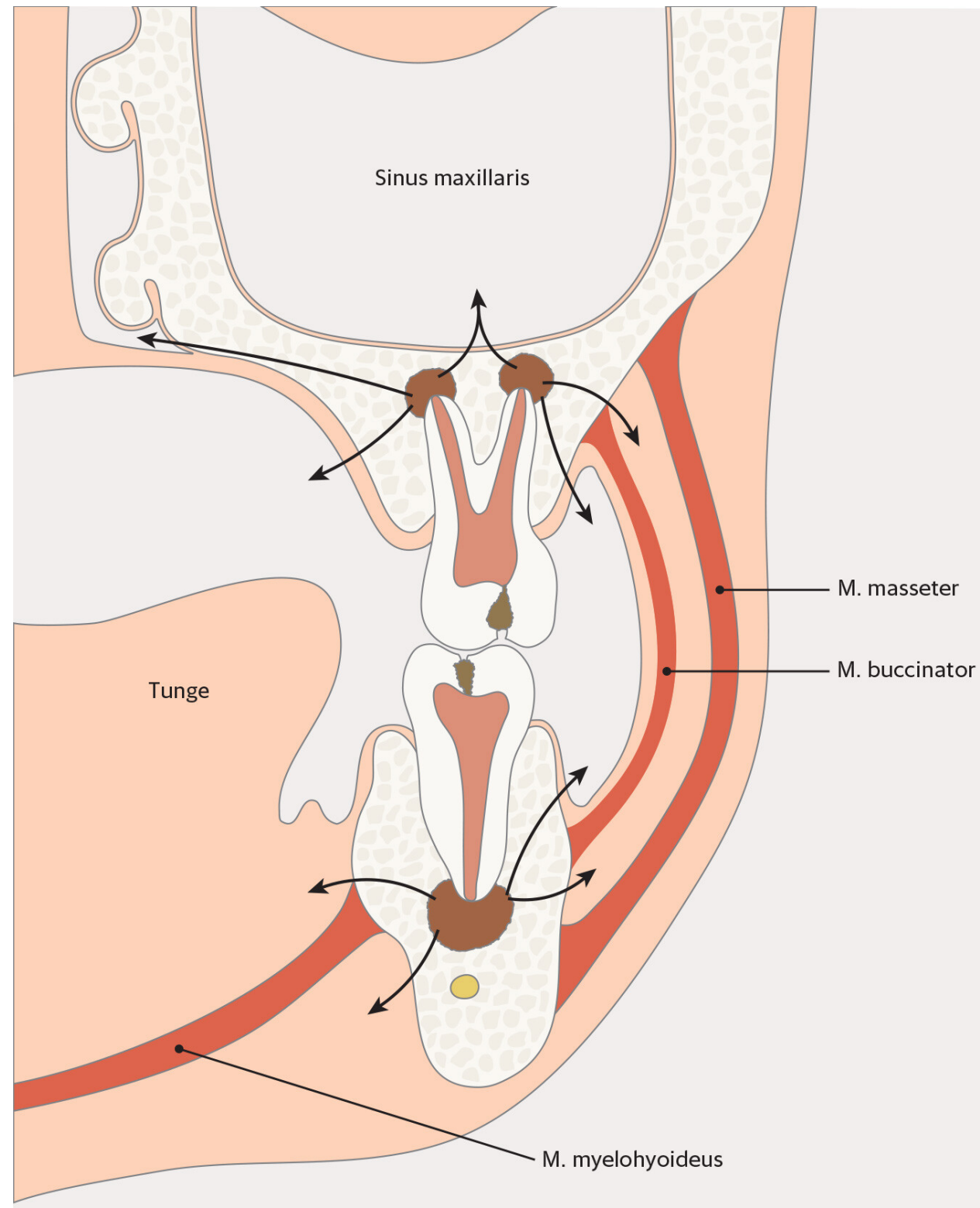

Figur 2 Mulige spredningsveier til periapikale infeksjoner utgående fra molarer i over- og underkjeve.

Dersom det foreligger tegn til systemisk påvirkning med nedsatt allmenntilstand, bør pasienten også behandles med antibiotika. I tillegg må infeksjonsfokus saneres, helst innen få dager, ved å rense ut rotkanalen ved endodontisk behandling (som rotfylling) eller ved ekstraksjon av tannen. Samme behandlingsprinsipper gjelder for abscesser med etablert fistel, hvor sanering av infeksjonsfokus vil føre til regress av fistelen.

\section{PERIKORONITT}

Perikoronitt er en infeksjon som oppstår i bløtvevet rundt delvis retinerte tenner (tenner som blir liggende i kjeven). Tilstanden oppstår i all hovedsak i tidlig voksen alder ved visdomstenner i underkjeven når matrester og andre fremmedlegemer samler seg mellom tannkjøttet og den delvis frembrudte kronen til tannen. Som oftest fører dette til en lavgradig, residiverende infeksjon med smerter, hevelse og rødme i omkringliggende gingiva. I noen tilfeller kan pasientene også ha trismus (kjevesperre), feber og nedsatt allmenntilstand.

Predisponerende faktorer er stress, menstruasjon og nylig gjennomgått/pågående annen sykdom. Perikoronitt er som regel selvbegrensende, men residiv er vanlig frem til tannen er frembrudt eller ekstrahert. I visse tilfeller kan det også tilkomme abscedering som krever incisjon og drenasje. Tenner med residiverende periokoronitt bør vanligvis ekstraheres i en rolig fase.

\section{Andre bakterielle infeksjoner med mulig odontogen etiologi}




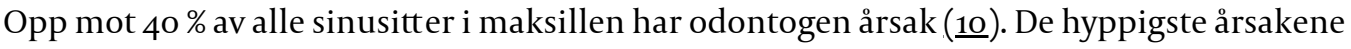
til odontogen maksillær sinusitt er apikal periodontitt, marginal periodontitt og

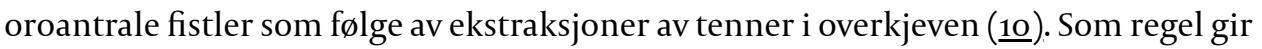
tilstanden smerter, slimhinneødem samt sekresjon fra nesen. I motsetning til rhinogen sinusitt er tilstanden som regel unilateral. Behandlingen består av sanering av dentalt fokus og eventuell elektiv funksjonell endoskopisk sinuskirurgi (FESS). Dersom årsaken skyldes persisterende oroantral fistel etter ekstraksjon av tann, kan denne lukkes kirurgisk av spesialist i maksillofacial kirurgi (medisinsk spesialitet) eller oral kirurgi (odontologisk spesialitet).

\section{OSTEOMYELITT}

Akutt bakteriell purulent osteomyelitt kan oppstå sekundært til infeksjon i tenner og deres støttevev. Infeksjonen har da spredd seg til kortikalt og spongiøst ben. Hyppigst er det underkjeven som affiseres, og pasientene har ofte sterke smerter, feber, pussekresjon fra området, trismus og dårlig ånde på grunn av tilstedeværelse av anaerobe bakterier (11). I tillegg kan det foreligge parestesi eller hypoestesi i underleppen og haken grunnet affeksjon av n. alveolaris inferior. Ved forsinket behandling kan en akutt osteomyelitt gå over i en kronisk fase. Kronisk osteomyelitt har som regel mildere symptomer enn den akutte formen og kjennetegnes av sekvesterdannelse og eventuell fistulering (1ㅡ).

Computertomografi (CT), panoramarøntgen (OPG) eller magnetisk resonanstomografi (MR) kan vise varierende grad av osteolyse, osteosklerose og sekvestre. Behandlingen er antibiotika, drenasje dersom det foreligger abscess og eventuelt kirurgisk revisjon i regi av maksillofacial- eller oralkirurg med fjerning av infisert, nekrotisk vev. I tillegg må utløsende årsak behandles, for eksempel ved endodontisk behandling eller ekstraksjon av $\operatorname{tann} /$ tenner.

\section{NEKROTISERENDE FASCIITT}

Nekrotiserende fasciitt er en alvorlig, destruktiv og progressiv bløtvevsinfeksjon som raskt kan bli livstruende. Sykdommen deles inn i to subtyper på bakgrunn av hvilke bakterier som er ansvarlige. Type 1 forårsakes av streptokokker (ikke gruppe A), enterobakterier,

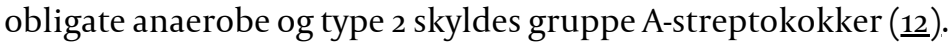

Tilstanden begynner med trombosering i småkar i periferien av infeksjonsfokus, som fører til akutt inflammasjon, ødem i subkutant vev og eventuelt hud (figur 3). Det tilkommer så nekroser i det infiserte vevet, som raskt sprer seg langs overfladiske fascier, nerver, arterier

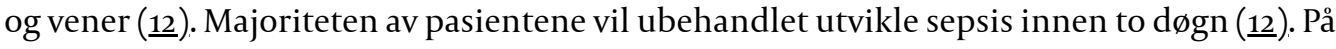
grunn av god vaskularisering oppstår nekrotiserende fasciitt sjelden i hode- og halsområdet, med en rapportert årlig insidens på 2 per $1000000(\underline{12})$. Den vanligste utløsende årsaken til nekrotiserende fasciitt i hode- og halsområdet er odontogen infeksjon, men tilstanden kan oppstå sekundært til blant annet faryngitt, tonsillitt, akutt

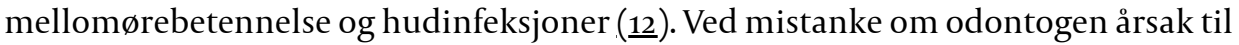
nekrotiserende fasciitt bør pasienten henvises akutt til kjeve- og ansiktskirurgisk avdeling, alternativt til nærmeste øre-nese-hals-avdeling eller plastikkirurgisk avdeling. 


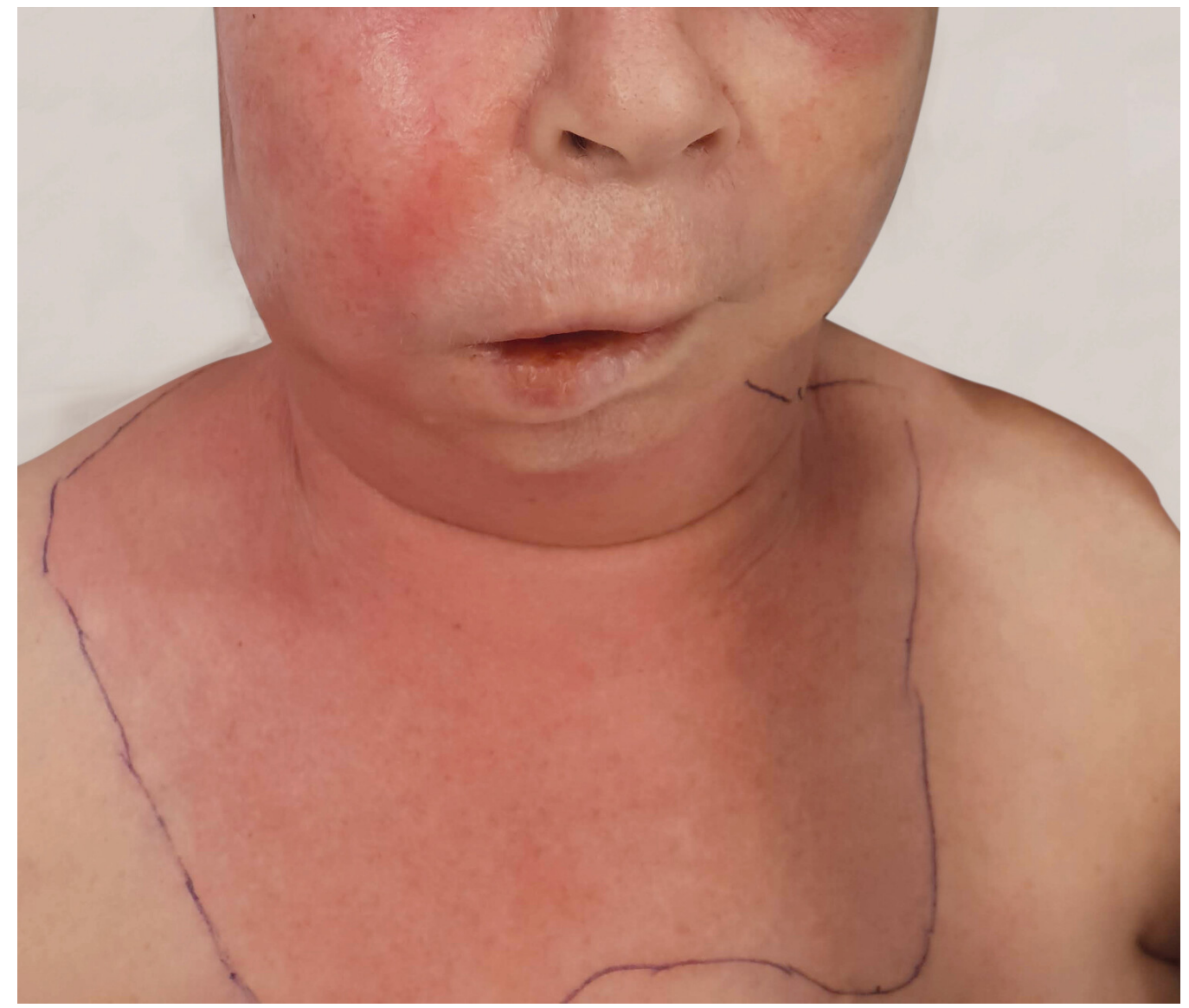

Figur 3 Nekrotiserende bløtvevsinfeksjon utgående fra periapikal abscess på molar i overkjeven på høyre side.

CT med kontrast er nødvendig for å vurdere lokalisasjon og utbredelse av infeksjonen samt å avdekke eventuelt primærfokus som for eksempel periapikale oppklaringer på tannrøtter. Denne kan vise asymmetrisk fasciefortykkelse, gassbobler langs fascieplan, ødematøs muskulatur og bløtvev og eventuell væskeansamling i fascielosjene som tegn på abscess (13). Rask behandling med radikal kirurgisk debridement av nekrotisk vev og antibiotikabehandling er viktig. Nasjonale retningslinjer anbefaler

kombinasjonsbehandling med cefotaksim og metronidazol med eventuelt tillegg av klindamycin (14.).

\section{LUDWIGS ANGINA}

Ludwigs angina ble først beskrevet av den tyske legen Friedrich von Ludwig i 1836, og er en raskt progredierende infeksjon submandibulært og sublingvalt. Infeksjonen er som regel ikke abscederende, men flegmonøs og diffus i utbredelsen på begge sider av munngulvets midtlinje. Pasientene har som oftest nedsatt allmenntilstand, feber og uttalt submandibulær hevelse. Tungen kan hovne opp og presses ut av munnen, retrofaryngealt eller opp i ganen og føre til obstruksjon av øvre luftveier. Infeksjonen kan også gi truet luftvei ved at den spres til laterale halslosje eller retrofaryngealt.

Ubehandlet har tilstanden en dødelighet på rundt 50 \%, og årvåkenhet med tanke på sikring av luftvei er svært viktig (15). Pasientene må derfor henvises akutt til sykehus med maksillofacial kirurg eller øre-nese-hals-lege. Hyppigste årsak til Ludwigs angina er odontogene infeksjoner fra andre og tredje molar i underkjeven, fordi røttene til disse ligger kaudalt for m. myelohyoideus (15). Andre utløsende årsaker er blant annet peritonsillær eller parafaryngeal abscess, sekundærinfisert mandibelfraktur eller submandibulær sialoadenitt (15). CT med intravenøs kontrast anbefales for å vurdere infeksjonens utbredelse og hvorvidt det foreligger abscedering. Rask diagnose er viktig for å starte opp med tidlig antibiotikabehandling sammen med incisjon og drenasje ved

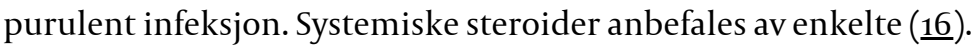


Dersom en odontogen infeksjon spres dorsolateralt til den laterale halslosjen, kan dette føre til septisk tromboflebitt i vena jugularis interna. Tilstanden er sjelden, med en rapportert årlig insidens på 3,6 per 1000 ooo (17.). Det er imidlertid økende antall publiserte tilfeller av tilstanden, som trolig skyldes $ø$ kt kunnskap samt forbedret bildediagnostikk (17.). Syndromet rammer oftest tidligere friske barn og unge voksne.

Den vanligste utløsende årsaken er forutgående viral faryngitt. Trolig fører dette til nedsatt barriere i mucosa, som igjen fører til migrasjon av bakterier inn i dypere vev. Opportunistiske gramnegative staver i form av fusobakterier er rapportert som hyppigste agens, men inntil en tredjedel av tilfellene er polymikrobielle (17.). I de fleste tilfeller foreligger det bakteriell embolisering, hyppigst i lunger og store ledd, men det er også rapportert om septiske embolier i hjerne, hud, lever og perikard (17.). Foruten symptomer og funn fra eventuelle embolier har pasientene ofte unilaterale smerter i nakken, feber, trismus, palpabel oppfylning svarende til vena jugularis interna og oppvekst av bakterier i blodkultur.

Behandlingen består av langvarig antibiotikabehandling, som har bedret prognosen fra en mortalitetsrisiko på 9o \% i preantibiotiske tider til under o-18 \% i moderne tid (177, 18 ). Antikoagulasjon er omdiskutert. Avhengig av etiologi bør man for pasienter med Lemierres syndrom konferere med avdeling for kjeve- og ansiktskirurgi eller øre-nese-hals.

\section{SPREDNING TIL DYPE HALSFASCIELOSJER}

Infeksjonsspredning til de dype halslosjene kan være alvorlig. Det finnes minst 11 dype halslosjer som er definert av de forskjellige fasciene i ansiktet og på halsen. Majoriteten av de dype halsinfeksjonene skyldes spredning fra primære odontogene infeksjoner (19). Spredningen går minste motstands vei langs fasciene, og kan blant annet føre til trombose i sinus cavernosus, cerebral abscess, meningitt, mediastinitt og perikarditt (19).

Symptomer og funn avhenger av infeksjonens lokalisasjon. Dette kan være feber, nedsatt allmenntilstand, hevelse, smerte ved svelging, dysfagi, heshet, stridor og trismus. Hevelse kan føre til kompresjon av trakea med påfølgende truet luftvei. CT med kontrast kan både vise infeksjonens lokalisasjon og hvorvidt den er flegmonøs eller abscederende. Rask behandling med antibiotika og eventuell kirurgisk drenasje av puss er viktig. På lik linje med Lemierres syndrom bør etiologi bestemme behandlingssted.

\section{Konklusjon}

Ukompliserte, lokale odontogene infeksjoner forekommer hyppig og kan som regel håndteres av tannlege. I enkelte tilfeller kan odontogene infeksjoner utvikles til alvorlige tilstander med betydelig morbiditet. Det er derfor viktig å kjenne til tilstandene og ved mistanke om disse henvise pasienten til sykehus med kompetanse innen maksillofacialeller hode-hals-kirurgi.

Pasientene har samtykket til at bildene med bildetekst blir publisert.

Artikkelen er fagfellevurdert.

1. Andersson L, Kahnberg KE, Pogrel MA. Oral and maxillofacial surgery. 1. utg. Wiley-Blackwell, 2010.

2. Krishnan K, Chen T, Paster BJ. A practical guide to the oral microbiome and its relation to health and disease. Oral Dis 2017; 23: 276-86. [PubMed][CrossRef] 
3. Olsen I, Taubman MA, Singhrao SK. Porphyromonas gingivalis suppresses adaptive immunity in periodontitis, atherosclerosis, and Alzheimer's disease. J Oral Microbiol 2016; 8:33029. [PubMed] [CrossRef]

4. Komine-Aizawa S, Aizawa S, Hayakawa S. Periodontal diseases and adverse pregnancy outcomes. J Obstet Gynaecol Res 2019; 45: 5-12. [PubMed][CrossRef]

5. Leal ASM, de Oliveira AEF, Brito LMO et al. Association between chronic apical periodontitis and low-birth-weight preterm births. J Endod 2015; 41:353-7. [PubMed][CrossRef]

6. Eke PI, Dye BA, Wei L et al. Prevalence of periodontitis in adults in the United States: 2009 and 2010. J Dent Res 2012; 91: 914-20. [PubMed][CrossRef]

7. Skudutyte-Rysstad R, Eriksen HM, Hansen BF. Trends in periodontal health among 35-year-olds in Oslo, 1973-2003. J Clin Periodontol 2007; 34: 867-72. [PubMed][CrossRef]

8. Cullinan MP, Seymour GJ. Periodontal disease and systemic illness: will the evidence ever be enough? Periodontol 2000 2013; 62: 271-86. [PubMed][CrossRef]

9. Nair PN. On the causes of persistent apical periodontitis: a review. Int Endod J 2006;39: 249-81. [PubMed][CrossRef]

10. Kim SM. Definition and management of odontogenic maxillary sinusitis. Maxillofac Plast Reconstr Surg 2019; 41:13. [PubMed][CrossRef]

11. Baltensperger M, Eyrich G. Osteomyelitis of the jaws. I: Baltensperger MM, Eyrich GKH, red. Osteomyelitis of the jaws. Berlin, Heidelberg: Springer Berlin Heidelberg, 2009: 5-56.

12. Wolf $\mathrm{H}$, Rusan M, Lambertsen $\mathrm{K}$ et al. Necrotizing fasciitis of the head and neck. Head Neck 2010; 32: 1592-6. [PubMed][CrossRef]

13. Wysoki MG, Santora TA, Shah RM et al. Necrotizing fasciitis: CT characteristics. Radiology 1997; 203: 859-63. [PubMed][CrossRef]

14. Helsedirektoratet. Nasjonal faglig retningslinje for antibiotikabruk i sykehus. https://www.helsedirektoratet.no/retningslinjer/antibiotika-i-sykehus/hud-ogblotdelsinfeksjoner/nekrotiserende-blotdelsinfeksjoner Lest 30.11.2019.

15. Candamourty R, Venkatachalam S, Babu MR et al. Ludwig's Angina - An emergency: A case report with literature review. J Nat Sci Biol Med 2012;3: 206-8. [PubMed][CrossRef]

16. Busch RF, Shah D. Ludwig's angina: improved treatment. Otolaryngol Head Neck Surg 1997; 117: S172-5. [PubMed][CrossRef]

17. Eilbert W, Singla N. Lemierre's syndrome. Int J Emerg Med 2013; 6: 40. [PubMed][CrossRef]

18. Noy D, Rachmiel A, Levy-Faber D et al. Lemierre's syndrome from odontogenic infection: Review of the literature and case description. Ann Maxillofac Surg 2015; 5: 219-25. [PubMed][CrossRef]

19. Kataria G, Saxena A, Bhagat S et al. Prevalence of odontogenic deep neck space infections (DNSI): a retrospective analysis of 76 cases of DNSI. International Journal of Otorhinolaryngology and Head and Neck Surgery 2015; 1: 11. [CrossRef]

Publisert: 28. april 2020. Tidsskr Nor Legeforen. DOI: 10.4045/tidsskr.19.0778

Mottatt 30.11.2019, første revisjon innsendt 1.2.2020, godkjent 24.2.2020.

(C) Tidsskrift for Den norske legeforening 2023. Lastet ned fra tidsskriftet.no 26. april 2023. 